\title{
Os primeiros passos de Lobato nas décadas de 20 e 30: da oralidade a novas descobertas sobre o gosto infantil'
}

\author{
The First Steps of Lobato in the 20's and 30's Decades: From Orality \\ to the Recent News on Children's Taste and Preferences
}

\author{
IZAURA DA SILVA CABRAL \\ Universidade Federal do Rio Grande do Sul-CAPES \\ Brasil \\ iza-cabral@hotmail.com
}

(Recibido: 2I-O5-20I4; aceptado: 29-O5-2OI4)

\begin{abstract}
Resumo. No Brasil, um dos precursores da literatura infantil é Monteiro Lobato, que aproveitou algumas das características experimentadas por outros e o fato de a escola da época estar começando a inserir os livros de leitura no cotidiano escolar, para produzir livros destinados aos pequenos. Dessa forma, buscaremos identificar a construção de sua obra infantil, especialmente as descobertas sobre a preferência dos leitores infantis durante os anos 20 e 30, como a presença da oralidade e outras características, claramente registradas nas reedições de suas obras. Tomaremos como corpus da análise as edições de $\mathrm{A}$ menina do narizinho arrebitado (1920) e o primeiro capítulo "Narizinho arrebitado" (1934) de Reinações de Narizinho.A partir da análise, pode-se verificar as razões que levaram Monteiro Lobato a realizar alterações visando atingir o leitor infantil, resultado que o consagrou como um dos maiores autores da literatura infantil brasileira de todos os tempos.
\end{abstract}

Palavras-chave: Literatura infantil; Monteiro Lobato; Reinações de Narizinho; leitor infantil; anos 20 e 30.
Abstract. In Brazil, one of the forerunners of children's literature is Monteiro Lobato, an author who took notice of some of the characteristics experienced by others and of the fact that the school of those times was starting to introduce reading into the daily activities of school, at the same time that books targeted to children were being produced. Thus, we will seek to identify the construction of work on children, especially the findings on the preferences of infant readers during the ' 20 s and ' 30 s of the XXth century, as it is the case of orality and other features clearly recorded in the editions of his works. We will undertake an analysis taking as corpus the editions of The Girl Upturned Little Nose (1920) and the first chapter "Narizinho snub" (1934) of the Reinações Narizinho. From this analysis, one can see the reasons why Monteiro Lobato made changes in order to reach children readers. It served to establish himself as one of the greatest authors of Brazilian children's literature of all time.

Keywords: Children's Literature; Monteiro Lobato; Reinações of Narizinho; children's Lite Reader; 20's and 30's decades of the XXth century.

\footnotetext{
${ }^{\text {I }}$ Para citar este artículo: Cabral, Izaura DaSSilva (20I5). Os primeiros passos de Lobato nas décadas de 20 e 30 : da oralidade a novas descobertas sobre o gosto infantil. Alabe 11. [www.revistaalabe.com]

DOI: IO.I5645/Alabe.2OI5.II.I
} 


\section{I-. O início de tudo}

A literatura infantil como gênero tem uma história bastante recente, uma vez que o seu surgimento está diretamente ligado à história da infância, a partir do momento em que a criança passou a ser vista como um ser em formação e necessitava uma produção cultural adequada a seu nível intelectual e social. No Brasil, um dos precursores da literatura infantil é Monteiro Lobato, que aproveitou algumas das características experimentadas por outros escritores e pelo fato de a escola da época estar começando a inserir os livros de leitura. Levando em consideração o contexto, e com o propósito de realizar esse trabalho, será identificado o caminho de Lobato na construção de sua obra infantil, especialmente com as suas descobertas sobre a preferência dos leitores infantis durante os anos de 20 e 30 , claramente registrada nas reedições de suas obras, bem como suas descobertas a cerca das características dos livros que agradam ao leitor criança até hoje. Tomaremos como corpus de estudo as edições de $A$ menina do narizinho arrebitado (I920) e o primeiro capítulo "Narizinho arrebitado" (I934) de Reinações de Narizinho. Ainda, a partir da análise, pretendemos entender as razões que levaram Monteiro Lobato a realizar alterações visando atingir o leitor infantil, resultado que o consagrou como um dos maiores autores da literatura infantil brasileira de todos os tempos.

Nas últimas décadas do século XIX, no Brasil, houve a ascensão da classe média urbana. Essa classe média responsabiliza-se pelas mudanças ocorridas no país, e em nome dela, revoluções, avanços e retrocessos ocorrem. $\mathrm{O}$ aparecimento dos primeiros livros para crianças incorpora-se a esse processo, porque atende às solicitações indiretamente formuladas pelo grupo social emergente. Tendo em vista que não havia nada especialmente produzido aos pequenos, a maneira encontrada para atingir esse público foi traduzir obras estrangeiras, adaptar obras destinadas originalmente aos adultos, reciclar material escolar, já que os leitores que formavam o crescente público eram igualmente alunos e estavam se habituando a utilizar o livro didático, apelar para a tradição popular, confiando em que as crianças gostariam de encontrar nos livros histórias parecidas àquelas que as mães, amas-de-leite, escravas e ex-escravas contavam em voz alta, desde quando elas eram bem pequenas. Podemos dizer que a tradição popular trouxe contribuições para o surgimento de uma literatura destinada aos pequenos, assim como os contos de fadas europeus que continuam sendo lidos até hoje.

Dessa maneira, vários foram os autores brasileiros que traduziram ou adaptaram obras para as crianças, seguindo modelos europeus, os precursores foram Carl Jansen, Olavo Bilac e Figueiredo Pimentel (I869-I9I4) que publicou coletâneas de muito sucesso, como os Contos da Carochinha (I894), em que encontram as histórias de fada européias, ao lado de narrativas coletadas entre os descendentes dos povoadores do Brasil. Assim foi como a tradição oral e popular se enraizou no Brasil para não mais sair, e Lobato foi o sucessor desse núcleo original. 


\section{2-. Buscando o leitor infantil}

Esse núcleo original deixou heranças a seu sucessor, como já dissemos, com personagens e histórias da tradição oral, que foram contribuindo para que Lobato empreitasse seus primeiros passos na produção de livros para as crianças. Ele foi o homem das revoluções. A alavancada que deu na indústria livreira nacional foi uma delas. As outras foram à luta pelo petróleo e a literatura infantil. Antes dele não existia a literatura como atividade comercial. Escrevia-se para entrar na Academia, para se tornar imortal. Para isso, escrevia-se numa linguagem empolada que tinha como objetivo não agradar ao leitor, mas fazer gênero. O criador do Sítio odiava isso. A desgraça da maior parte dos livros é o excesso de literatura, e esse é um dos objetivos do autor, extrair toda a "literatura" de seus livros, construindo livros em que as crianças pudessem morar.

Podemos perceber a preocupação com a criança e a visão da infância tipicamente moderna para a época, como destaca Nunes (1986, p. 48), em uma carta de Lobato a Vicente Guimarães em doze de janeiro de mil novecentos e trinta e seis: "uma coisa que sempre me horrorizou foi ver o descaso do brasileiro pela criança, isto é, por si mesmo, visto como a criança não passa da nossa projeção para o futuro". Para Lobato a criança era um público em potencial e necessitava de leitura apropriada à fase que se encontrava e a seu gosto.

Dessa maneira, $o$ autor inicia suas primeiras produções infantis como destaca Cavalheiro (I956), contando que a ideia da primeira historia infantil escrita pelo autor teria surgido em I92O, quando ele era também editor:

Certa tarde, na Editora, joga xadrez com Toledo Malta, quando no intervalo entre dois lances, este lhe conta a história de um peixinho que por haver passado um tempo fora d'água "desaprendera a nadar", e de volta ao rio afogara-se. "Perdi a partida de xadrez naquele dia, talvez menos pela perícia do jogo do Malta do que por causa do peixinho. O tal peixinho pusera-se a nadar em minha imaginação, e quando Malta saiu, fui para a mesa e escrevi a "Historia do Peixinho que Morreu Afogado" - coisa curta. Do tamanho do peixinho. Publiquei isso logo depois, não sei onde. Depois veio-me a ideia de dar maior desenvolvimento a historia, e ao fazê-lo acudiram-me cenas da roca, onde eu havia passado a minha meninice.

Conforme Arroyo (I968, p. 200), a partir do pequeno conto "A história do peixinho que morreu afogado" Lobato começa a reviver histórias de sua infância na roça e cria personagens e ambientes que o remetiam a pessoas como a "mulata Joaquina", com quem ia pescar lambaris no Ribeirão; da primeira entrada na floresta em companhia do pai; das brincadeiras com as irmãzinhas; das histórias contadas por Evaristo. As cenas foram vindo à tona em sua memória, e quando se deu por conta, produzia as primeiras linhas da grande obra destinada aos pequenos, como aponta Cavalheiro (1956): 


\begin{abstract}
"Naquela casinha branca, lá muito longe, mora D. Benta de Oliveira, uma velha de mais de setenta anos". Por que velha? Por que Benta? Velha, porque se iam entrar crianças, era preciso botar uma velha, uma vovó, pois só as vovós aturam crianças e deixam-nas fazer o que querem. E Benta, por que? Num colégio em que estivera em Taubaté, havia um rapaz de nome Pedro de Castro, que às vezes contava histórias de sua avó Benta, lá de Macaé. E o conto foi brotando, ao sabor da fantasia, um pedaço hoje, outro amanhã, os intervalos que, no escritório, lhe deixavam as partidas de xadrez (...)
\end{abstract}

De acordo com Arroyo (1968, p. 200) com essa história do peixinho nasceu o livro A menina do Narizinho Arrebitado, o peixinho puxou a imaginação do escritor, e a obra foi muito bem recebida, Bruno Ferraz (apud Cavalheiro: 1962, p. I46-I50). Em I920, Lobato publica então seu livro dedicado aos pequenos, com capa ilustrada a partir de desenhos feitos por Voltolino.

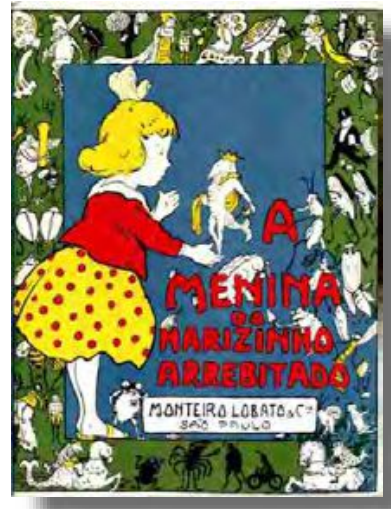

Capa de fac-símile da primeira edição de $A$ menina do narizinho arrebitado.

Muitos, na época manifestaram a sua opinião sobre a nova obra que era lançada, inclusive Menotti del Picchia foi um deles, publicando-a jornal Correio Paulistano, de 23/I2/1920:

Um belo presente de Natal de I92O para esses milhões de serezinhos que ainda acreditam em sortilégios e fadas. Senhor de um mágico estilo, feito para deslumbrar adultos, soube - e nisto está o grande elogio da sua obra - criar uma linguagem comovida e simples para, com ela nivelado em nossos pequerruchos, falar à ingênua imaginação das crianças.

Depois de ser publicado como livro, no final de I920, com o título $A$ menina do narizinho arrebitado, a obra aparece em episódios (como continuação do livro publicado em 20), na Revista do Brasil, em I92I, sendo que alguns dos episódios são publicados na revista sob o título Lúcia ou A menina do narizinho arrebitado.

Em carta ao amigo e professor Godofredo Rangel, Lobato manifesta a ideia de testar o livro na escola e decide realizar uma campanha pela leitura escolar. Segundo 
Arroyo (I968, p. 204), Lobato não escrevia à toa para Rangel, ele queria a impressão de professor acostumado a lidar com crianças. A sua obra com o título de Narizinho arrebitado é aprovado pelo governo de São Paulo para uso em escolas públicas. E em I92I sai uma edição de $5^{\mathrm{O} .5 \mathrm{OO}^{2}}$ exemplares com as ilustrações em preto e branco de Voltolino, feita de papel jornal.

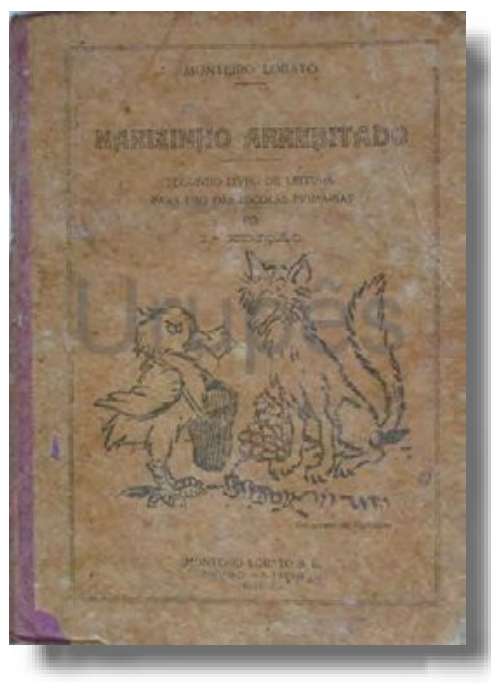

Durante os anos 20 e 30, Lobato continuou publicando livros, clássicos da literatura infantil, como Grimm, Andersen e Perrault. Seu entusiasmo não se restringiu a essas publicações, pois em 1934 nasceu a sua ideia de reunir as várias aventuras de Narizinho, que segundo Arroyo (I968, p. 205), foram pequenos tomos intitulados Narizinho Arrebitado (I92I), Noivado de Narizinho (I928), Aventuras do Príncipe (I928), Pena de Papagaio, Gato Félix, Cara de Coruja, O Irmão de Pinóquio, O circo dos Escavalinhos, Pó de Pirlimpimpim, No País das Abelhas e Novas Reinações de Narizinho, que como disse o próprio Lobato (I944, p. 495) seria a "consolidação num volume grande dessas aventuras que tenho publicado por partes, com melhorias, aumentos e unificação num todo harmônico".

O exame dessas alterações feitas nas primeiras obras infantis publicadas por Lobato pode ser revelador no sentido de nos apontar o seu caminho para o sucesso, como escritor da literatura infantil brasileira, poderemos observar como ele lapidou seu estilo sempre com um único objetivo, o de conquistar o leitor criança. Dessa forma, vamos iniciar a análise pelo primeiro parágrafo da obra, que apresenta os protagonistas da história.

\footnotetext{
${ }^{2}$ De acordo Cavalheiro (I962, p. 4I7), o exame da companhia Editora Nacional, contudo, revela uma edição de 6o.ooo exemplares. Os arquivos pertenceram à Gráfica Monteiro Lobato. Segundo Cavalheiro, Lobato distribuíra, num lúcido lance de propaganda, 5 oo exemplares para escolas e grupos escolares do Estado de São Paulo.
} 


\begin{tabular}{|l|l|}
\hline A menina do narizinho arrebitado (1920) & \multicolumn{1}{|c|}{ Narizinho arrebitado (1934) } \\
\hline Naquela casinha branca, - lá muito longe, & Numa casinha branca, lá no sitio do \\
mora uma triste velha, de mais de setenta & Picapau Amarelo, mora uma velha de mais \\
anos. Coitada! Bem no fim da vida que & de sessenta anos. Chama-se dona Benta. \\
está, e tremula, e catacega, sem um só & Quem passa pela estrada e a vê na varanda, \\
dente na boca - jururu... Todo o mundo & de cestinha de costura e óculos de ouro na \\
tem dó d'ela: & ponta do nariz, segue seu caminho \\
- Que tristeza viver sozinha no meio do do & pensando: \\
mato... & $\begin{array}{l}\text { Que tristeza viver assim tão sozinha } \\
\text { nesse deserto... }\end{array}$ \\
\hline
\end{tabular}

Podemos analisar algumas alterações como o espaço, que de um modo realista, se apresentava próximo e visível ao leitor "naquela casinha branca”, torna-se distante, indeterminado como nos contos populares ou maravilhosos "numa casinha branca, lá no Sítio do Picapau Amarelo". Quanto ao aspecto observado, podemos dizer que a característica de espaço e tempo indeterminados é uma dos elementos que agrada aos pequenos leitores, já os conceitos ainda não foram construídos pela criança, na infância ainda não há diferenças claras entre o "aqui" e o "lá", sendo absolutamente possível descolar-se de um para outro sem perceber a distância

Além disso, as personagens passam para uma dimensão afetiva, tornando-se mais próximas do leitor, proporcionando uma maior identificação. D. Benta, em lugar de "uma triste velha [...] trêmula e catacega", passa a ser apresentada como "uma velha de mais de sessenta anos" muito ativa com suas costuras e "óculos de ouro na ponta do nariz". Os adjetivos foram enxugados; a velhinha "triste" e "coitada", "quase no fim da vida" da primeira edição desaparece. A descrição de características físicas - "trêmula", "catacega", "sem um dente na boca" - dá lugar a apresentação nominal "chama-se Dona Benta”, e esta pode ser outra característica que agrada ao leitor, de acordo com Cabral (2007, p.84), "na análise de personagens, um dos primeiros signos que aparece é o nome próprio, que oferece uma dimensão conotativa, pois destaca a intensidade nominal e dela faz derivar a função narrativa", além disso, a partir disso a "a criança pode encontrar na ficção a situação próxima dela, contribuindo para uma maior identificação com o relato".

Inclusive, a velha está com uma cestinha de costura, o que indica a prática de um trabalho que exige firmeza das mãos; e o enfraquecimento da visão, antes apresentado negativamente - ela é “catacega”. Apesar das alterações, Dona Benta continuou sendo a primeira personagem a aparecer na história.

Durante os anos que passaram desde a publicação de $A$ menina do narizinho arrebitado em I920, mesmo com a descrição que apresenta uma avó mais ativa, talvez tenha sido necessário rejuvenescê-la, ainda que na versão compilada deı934, sua idade continue não explicitada, é diminuída: ela passa a ter "mais de sessenta anos", em lugar de "mais de setenta". 


\section{A menina do narizinho arrebitado}

Pois estão enganados. A velha vive feliz e bem contente da vida, graças a uma netinha órfã de pai e mãe, que lá mora des'que nasceu. Menina morena, de olhos pretos como duas jaboticabas - e reinadeira até ali!... Chama-se Lúcia, mas ninguém a trata assim. Tem apelido. Yayá? Nenê? Maricota? Nada disso. Seu apelido é "Narizinho Arrebitado", - não é preciso dizer porquê.

\section{Narizinho arrebitado}

Mas engana-se. Dona Benta é a mais feliz das vovós, porque vive em companhia da mais encantadora das netas - Lúcia, a menina do narizinho arrebitado, ou Narizinho, como todos dizem. Narizinho tem sete anos, é morena como jambo, gosta muito de pipoca e já sabe fazer uns bolinhos de polvilho bem gostosos.

Nas duas versões a razão da alegria de dona Benta é a neta. Entretanto, há algumas diferenças significativas relacionadas à maneira como a menina é apresentada ao leitor. A orfandade de Narizinho "netinha órfã de pai e mãe", mencionada na primeira versão, fica apenas implícita na última. Outro aspecto a ser notado é o modo como o autor introduz o apelido da personagem, na versão de I920, o narrador, chamando o leitor para o diálogo, sugere três nomes antes de dar a conhecer o apelido "Narizinho Rebitado": Yayá, Nenê e Maricota.

Narizinho deixa de ser a netinha órfã, não mais mostrando logo no início que a personagem poderia ser triste com sua situação, apresentada como "menina morena, de olhos pretos como duas jaboticabas - e reinadeira até ali!”, para aparecer com uma personalidade ativa e positiva: "a mais encantadora das netas [...] tem sete anos e morena como jambo, gosta muito de pipoca e já sabe fazer bolinhos de polvilho bem gostosos”. Sua idade - explícita na versão final - antecipa a descrição de suas qualidades como vimos. Além da idade que identifica o leitor, também podemos observar a presença de alimentos tipicamente populares.

\begin{tabular}{|c|c|}
\hline$A$ & \\
\hline $\begin{array}{l}\text { Além de Lúcia, existe } \\
\text { a Nastácia, uma excelente } \\
\text { timação, e mais a Excel } \\
\text { enhora Dona Emília, uma b } \\
\text { ano, fabricada pela preta e mui } \\
\text { pobre, com seus olhos de retrc }\end{array}$ & $\begin{array}{l}\text { Apesar disso Narizinho gosta } \\
\text { muito dela; não almoça nem janta sem a ter } \\
\text { ao lado, nem se deita sem primeiro } \\
\text { acomodá-la numa redinha entre dois pés de } \\
\text { cadeira. } \\
\text { Além da boneca, o outro encanto } \\
\text { da menina é o ribeirão que passa pelos } \\
\text { fundos do pomar. Suas águas muito } \\
\text { apressadinhas e mexeriqueiras correm por }\end{array}$ \\
\hline
\end{tabular}


Tia Nastácia, de "excelente negra de estimação", é vista como "a negra de estimação que carregou Lúcia em pequena”. Podemos dizer que “Tia Nastácia” é o símbolo idealizado da raça negra, afetuosa e humilde, que está em nossa gênese de povo e foi a melhor fonte de histórias que alimentaram a imaginação e a fantasia de gerações e gerações de brasileiros. Aos que chamaram Lobato de racista, por criar essa personagem preta e ignorante, não perceberam que dentro de seu universo literário não há preconceito racial nenhum, já que ela é amada e respeitada por todos.

Emília que nesse livro ainda não havia sido realmente descoberta por Lobato, surge como "Senhora Dona Emília", cheia de tratamentos formais e passa a simplesmente "Emília" - tratamento mais familiar ficando sem alteração nos outros aspectos - mandona, mas brejeira.

O espaço, representado pelo ribeirão (tão importante na primeira edição), vai ser alterado substancialmente. Suas “águas tão claras que se veem as pedras do fundo e toda a peixaria miúda”, transformaram-se em "águas muito apressadinhas e mexeriqueiras, correndo por entre pedras negras de limo". Torna-se assim, mais verossímil essa versão do ribeirão, pois tendo "águas tão claras" que deixavam ver "toda a peixaria miúda”, é de se supor que o "Reino das Águas Claras" também deveria ser ali visível. Com a menção das águas correndo entre "pedras negras de limo", automaticamente no espírito do leitor, as águas se escurecem e obviamente escondem o que se passa no fundo do ribeirão.

\begin{tabular}{|c|c|}
\hline A menina do narizinho arrebitado & Narizinho arrebitado \\
\hline $\begin{array}{l}\text { Não se passa um dia sem } \\
\text { que Lúcia vá sentar-se à beira d'água, na } \\
\text { raiz de um velho ingazeiro, ali ficando } \\
\text { horas, a ouvir o barulhinho da corrente e a } \\
\text { dar comida aos peixes. E eles bem que a } \\
\text { conhecem! É vir chegando a menina e } \\
\text { todos lá vêm correndo, de longe, com as } \\
\text { cabecinhas erguidas, numa grande } \\
\text { faminteza. Chegam primeiro os piquiras, } \\
\text { os guarus barrigudinhos, de olhos } \\
\text { saltados; vêm depois os lambaris ariscos } \\
\text { de rabo vermelho; e finalmente uma ou } \\
\text { outra parapitinga desconfiada. }\end{array}$ & $\begin{array}{l}\text { Todas as tardes Lúcia toma a } \\
\text { boneca e vai passear à beira d'água, onde } \\
\text { se senta na raiz de um velho ingazeiro } \\
\text { para dar farelo de pão aos lambaris. } \\
\text { Não há peixe do rio que a não } \\
\text { conheça; assim que ela aparece, todos } \\
\text { acodem numa grande faminteza. Os } \\
\text { miúdos chegam pertinho; os graúdos } \\
\text { parece que desconfiam da boneca, pois } \\
\text { ficam ressabiados, a espiar de longe. }\end{array}$ \\
\hline
\end{tabular}

No todo, as alterações da primeira para a versão final revelam uma tentativa de tornar o popular e o afetivo mais presentes na narrativa. Além disso, a intenção didática na primeira versão se atenua ou praticamente desaparece na última. Notemos, por exemplo, a distância que vai entre um texto e outro na apresentação dos peixes do ribeirão. 
Os nomes dos peixes foram retirados e passam a ser caracterizados pelo porte ou comportamento. Na verdade, para as crianças, a nomenclatura que designa as espécies de peixes não tem a menor importância, isso é matéria de escola, além de ser um elemento a pesar na frase e na percepção da cena, sem lhe acrescentar nada. Inclusive, nesse trecho, já se percebe o maior espaço que a boneca vai ter no universo lobatiano: na primeira versão nem é mencionada na cena; na segunda, já atua sobre o comportamento dos peixes "alguns desconfiam da boneca, pois ficam ressabiados, a espiar de longe".

Além disso, podemos notar que Lobato preservou traços como a criação de palavras nas duas versões, como por exemplo, "faminteza", para mostrar que os peixes tinham muita fome. Essa estratégia agrada ao leitor infantil por ser esta uma característica tipicamente infantil, a criação de palavras para dizer o que querem, por que muitas vezes não encontram a palavra apropriada, já que não possuem um vocabulário tão amplo quanto ao do adulto.

\begin{tabular}{|c|c|}
\hline A menina do narizinho arrebitado & Narizinho arrebitado \\
\hline $\begin{array}{l}\text { - A entrada do meu reino é por } \\
\text { aqui - disse Escamado, apontando uma } \\
\text { furna entre as pedras e dando a mão à } \\
\text { menina para ajudá-la a subir. Entraram. } \\
\text { Mas a escuridão era pior que a de uma } \\
\text { noite sem estrelas, e Narizinho parou, } \\
\text { cheia de medo. O peixinho sorriu e disse: } \\
\text { - Os filhos dos homens só } \\
\text { enxergam quando há luz, mas os filhos } \\
\text { das águas são como as corujas: tanto vêem } \\
\text { no claro como no escuro. E puxou do } \\
\text { bolso um vagalume de olhos acesos, } \\
\text { pendurado num cabinho de arame. A } \\
\text { caverna clareou à luz da lanterna viva, e } \\
\text { Narizinho pôde ver que se achava num } \\
\text { corredor comprido, espécie de túnel... }\end{array}$ & $\begin{array}{l}\text { - É aqui a entrada do meu reino - } \\
\text { disse o príncipe. } \\
\text { Narizinho espiou, com medo de } \\
\text { entrar. } \\
\text { - Muito escura, príncipe. Emília é } \\
\text { uma grande medrosa. } \\
\text { A resposta do peixinho foi tirar do } \\
\text { bolso um vaga-lume de cabo de arame, } \\
\text { que lhe servia de lanterna viva. A gruta } \\
\text { clareou até longe e a "boneca" perdeu o } \\
\text { medo. Entraram... }\end{array}$ \\
\hline
\end{tabular}

Podemos perceber que "Escamado", na última versão, passa a ser chamado de "príncipe”, é esta outra maneira de aproximar o texto lobatiano aos contos de fadas, em que os príncipes não recebem nomes, apenas são príncipes e isso já basta para tornaremse encantadores para os leitores infantis. Nesse trecho, da primeira versão, Emília nem é mencionada, já na de I934, talvez Lobato, depois de ter escrito outros textos com a boneca muito atuante e que fizeram sucesso, tenha sacado que Emília era um elemento que desencadeava a imaginação das crianças, e passa a introduzi-la a todo o momento na narrativa. Inclusive aqui também podemos perceber a retirada da parte pedagógica do texto uma vez que todo trecho a seguir é retirado da última versão "os filhos dos homens só enxergam quando há luz, mas os filhos das águas são como as corujas: tanto vêem no claro como no escuro". Ainda a idéia de usar o vagalume para iluminar a gruta é uma grande diversão e essa permanece nas duas versões. 


\begin{tabular}{|c|c|}
\hline A menina do narizinho arrebitado & Narizinho arrebitado \\
\hline $\begin{array}{l}\text { - Bela coisa, mestre Agarra. } \\
\text { Vestido de mulher. Você o guarda do } \\
\text { palácio! } \\
\text { - Vestido de mulher? Eu? - disse } \\
\text { o sapo espantado. } \\
\text { - Mire-se neste espelho - disse o } \\
\text { príncipe. Só então o sapo percebeu a } \\
\text { judiaria de que tinha sido vítima. Ficou } \\
\text { apalermado, a olhar para o príncipe, para a } \\
\text { menina e para o espelho, sem nada } \\
\text { compreender do caso. }\end{array}$ & $\begin{array}{l}\text { - Bela coisa, Major! Dormindo } \\
\text { como um porco e ainda por cima vestido } \\
\text { de velha coroca... Que significa isto? } \\
\text { O sapo, sem compreender coisa } \\
\text { nenhuma, mirou-se apatetadamente num } \\
\text { espelho que havia por ali. E botou a culpa } \\
\text { no pobre espelho. }\end{array}$ \\
\hline
\end{tabular}

Aqui, na versão de I934 o nome do sapo desaparece e ele é chamado de Major. A cena do sapo "vestido de mulher" é enriquecida pelo fato dele estar "dormindo como um porco e ainda por cima vestido de velha coroca...”. Esses aspectos contribuem para que o texto se torne mais atraente para as crianças, reforçando a presença do humor. Além disso, para Sandroni ( 1987 , p. 59), o humor, a ironia e a crítica são também meios para reflexão na obra, o que pode proporcionar uma maior emancipação do leitor. O humor é gerado aqui pelo non-sense, que concebe o sapo como guarda do reino. De acordo com Chevalier e Gheerbrant (I998, p. 803), o medo do sapo faz dele um símbolo de fealdade e de falta de jeito, caracterizando-a.

Para Ana Maria Machado (2002, p. 20), a simples idéia de uma boa brincadeira proporcionada pela leitura também tem seu fundamento e pode ir além do mero entretenimento ou da diversão superficial e descartável. Quando brinca, a criança faz-de-conta. Fantasia, imagina, finge - cria uma ficção.

\begin{tabular}{|c|c|}
\hline A menina do narizinho arrebitado & \multicolumn{1}{|c|}{ Narizinho arrebitado } \\
\hline $\begin{array}{c}\text { Quero uma grande festa como } \\
\text { nunca houve igual. Avise a corte e dê as } \\
\text { ordens necessárias, mas antes de nada, } \\
\text { mande vir o coche real. }\end{array}$ & $\begin{array}{c}\text { Mande convite a todos os } \\
\text { O capitão saudou militarmente e e } \\
\text { nobres da corte para a grande festa que } \\
\text { visitante. E diga a mestre Camarão que } \\
\text { ponha o coche de gala para um passeio } \\
\text { pelo fundo do mar. Já. }\end{array}$ \\
$\begin{array}{c}\text { Naiu acompanhado dos guardas. } \\
\text { carruagemorou muito e uma uareceu à porta, puxada por } \\
\text { três parelhas de lambaris. } \\
\text { Servia de cocheiro um belo }\end{array}$ & \\
$\begin{array}{c}\text { camarão de libré vermelha, muito teso no } \\
\text { alto da boleia. Mal o príncipe e a menina } \\
\text { entraram na carruagem, mestre Camarão } \\
\text { estalou o chicote e os lambaris partiram } \\
\text { como raios. }\end{array}$ & \\
\hline
\end{tabular}

Nos trechos acima, podemos perceber a preocupação com a diminuição das descrições. Lobato com sua constante vontade de atrair mais leitores infantis, transforma o 
fragmento em apenas uma fala em discurso direto, o que traz mais dinamismo à leitura, e que deixa de lado as maçantes descrições que desagradam à criança leitora.

\begin{tabular}{|c|c|}
\hline A menina do narizinho arrebitado & Narizinho arrebitado \\
\hline $\begin{array}{l}\text { Narizinho não cabia em si de } \\
\text { gosto e mirando-se, ao espelho, duvidava } \\
\text { dos próprios olhos. } \\
\quad \text { - Serei eu mesma ou uma fada } \\
\text { das mil e uma noites? } \\
\text { (...) a orquestra rompeu a Valsa Real e o } \\
\text { príncipe, levantando-se, disse a menina: } \\
\text { - É chegada a nossa vez. Quer dar- } \\
\text { me a honra desta valsa? } \\
\text { Narizinho, que não queria outra } \\
\text { coisa, desceu do trono e nos braços do } \\
\text { príncipe rodopiou pela sala em giros tão } \\
\text { velozes que mais parecia um pião vivo. }\end{array}$ & $\begin{array}{l}\text { Narizinho vestiu-se, indo ver-se ao } \\
\text { espelho. } \\
\text { - Que beleza! exclamou, batendo } \\
\text { palmas. } \\
\text { Estou que nem um céu aberto! } \\
\text { E estava mesmo linda. Tão linda no } \\
\text { seu vestido de teia cor-de-rosa com } \\
\text { estrelinhas de ouro, que até o espelho } \\
\text { arregalou os olhos, de espanto. (...) } \\
\text { Narizinho e o príncipe dançaram a } \\
\text { primeira contradança sob os olhares de } \\
\text { admiração da assistência. Pelas regras da } \\
\text { corte, quando o príncipe dançava todos } \\
\text { tinham de manter-se de boca aberta e } \\
\text { olhos bem arregalados. Depois começou a } \\
\text { grande quadrilha. Foi a parte de que } \\
\text { Narizinho gostou mais. Quantas cenas } \\
\text { engraçadas! }\end{array}$ \\
\hline
\end{tabular}

Na edição de I920, o maior desejo da menina é dançar nos braços do príncipe e não cabe em si de tanta alegria: “- Serei eu mesma uma fada das mil e uma noites?”. Como a idade da menina não é explicita, a cena se torna mais romântica e ela se comporta como se fosse uma princesa jovenzinha dos contos de fadas.

Na versão de I934, “a parte” de que ela mais gosta não é nada romântica, são as cenas engraçadas provocadas pelos animaizinhos da corte, que dançam ao redor: "todos tinham de manter-se de boca aberta e olhos bem arregalados". Os esboços de princesa de conto de fadas da "primeira" Narizinho diluem-se a ponto de quase desaparecerem sob a ótica da transformação imperada por Lobato, caracterizado-a como um criança que se diverte para valer com as cenas engraçadas que presencia. Aqui também podemos destacar a sacada que o autor teve de colocar a menina como protagonista da história, visto que a criança na época ainda não era vista como potencial leitor, ele antecipou-se e colocou os pequenos como centro do enredo, capazes de brincarem e divertirem-se até mesmo através da leitura. Assim a infância passa a ter voz. 


\begin{tabular}{|c|c|}
\hline A menina do narizinho arrebitado & Narizinho arrebitado \\
\hline $\begin{array}{l}\text {... toda perturbada, ia responder, } \\
\text { quando uma voz conhecida a despertou: - } \\
\text { Narizinho, vovó está chamando! } \\
\text { A menina sentou-se na relva, } \\
\text { esfregou os olhos, viu o ribeirão a } \\
\text { deslizar como sempre e lá na porteira a } \\
\text { tia velha do lenço amarelo na cabeça. } \\
\text { Que pena! tudo aquilo não passara dum } \\
\text { lindo sonho... }\end{array}$ & $\begin{array}{l}\text {...Mas assim que entrou na sala de } \\
\text { baile, rompeu um grande estrondo lá fora } \\
- \text { o estrondo duma voz que dizia: - } \\
\text { Narizinho, vovó está chamando!... } \\
\text { Tamanho susto causou aquele } \\
\text { trovão entre os personagens do reino } \\
\text { marinho, que todos sumiram, como por } \\
\text { encanto. Sobreveio então uma ventania } \\
\text { muito forte, que envolveu a menina e a } \\
\text { boneca, arrastando-a do fundo do oceano } \\
\text { para a beira do ribeirãozinho do pomar. } \\
\text { Estavam no sítio de Dona Benta } \\
\text { outra vez! }\end{array}$ \\
\hline
\end{tabular}

Na primeira edição o autor valia-se da fantasia, mas ao mesmo tempo disciplinavaa com a lógica, como podemos ver no exemplo em que a aventura de Narizinho no Reino das Águas Claras termina no momento em que ela vai responder ao príncipe Escamado que a pede em casamento. Esclarecendo, nesse final que tudo não passara de um sonho, Lobato anula a presença do maravilhoso dentro do cotidiano. Deixa que predomine o pensamento racional sobre o pensamento mágico. $\mathrm{O}$ autor ainda não havia percebido que para a criança não há a separação entre os dois pensamentos e que eles podem conviver harmoniosamente.

Já na edição de I934, o real invade o fantástico quando em meio ao baile rompeu uma voz que chamava por Narizinho, voz comparada a um trovão e como por encanto todos os personagens do reino sumiram. Uma grande ventania trouxe as personagens de volta para casa. Essa é uma característica que agrada ao leitor infantil, já que para a criança em meio ao faz-de-conta tudo é possível, seres fantásticos visitarem o mundo real e vice-versa. Inclusive a viagem da personagem também pode representar o deslocamento do mundo real para uma aventura distante de casa, distante do conhecido. A presença desses elementos em textos que se tornaram clássicos pode demonstrar que as crianças de todos gostam de se aventurar pelo desconhecido, sair para longe de casa, mesmo que seja somente através da leitura, mas geralmente retornam, como é o caso de Narizinho e também de outras crianças protagonistas de textos clássicos infantis, como Peter Pan em Peter Pan, Dorothy em O mágico de Oz, Alice em Alice no país das maravilhas, Tom Sawyer em As aventuras de Tom Sawyer e tantos outros.

Durante a década que se passou desde a publicação de $A$ menina do narizinho arrebitado Lobato passou a conviver mais com as crianças e a observar através da leitura de seu livro escolar, o gosto infantil. A partir desse momento, ele vai conquistando seu estilo, ao se tornar consciente de que o mundo da criança é diferente daquele que o adulto vê. Cada vez mais se deixa contagiar pelo universo infantil (onde o real e o maravilhoso 
não se diferenciam...), e recorre aos cortes, reescritas e novas edições dos livros já publicados.

Além de todos os aspectos, podemos salientar que Lobato, na edição final, suprime cenas de violência e que tratam de críticas ao catolicismo, como um capítulo chamado de "A enfermaria". Na primeira versão temos a presença da pena da morte, chacinas e um vilão chamado de "Escorpião Negro", já na última, o papel do vilão é assumido pela Dona Carochinha, que recebe as críticas das personagens por apresentar histórias emboloradas e ultrapassadas para as crianças.

Conforme Cabral (2007), muitas vezes, as narrativas mirins criticam as instituições voltadas aos pequenos. Nesse caso, a crítica recai sobre as histórias que não agradam ao leitor infantil, principalmente aquelas com personagens autoritários como Dona Carochinha, que, por essa característica, se tornam ultrapassadas: "Dobre a língua! gritou vermelha de cólera. Velha coroca é vosmecê, e tão implicante que ninguém mais quer saber das suas histórias emboloradas". Da mesma forma Marçolla (2003), nos aponta que Lobato ao falar das histórias de dona Carochinha, antigas e com pouco significado, porque eram traduzidas ao pé da letra, sem a busca de adequação à língua, apresenta essas críticas, mostrando a revolta dos personagens da própria obra, levando ao exagero, pois nem eles se suportam mais, guardados nos velhos livros.

Algumas das alterações efetuadas por Monteiro Lobato, conforme Marçolla (2003) mostram “a sua preocupação ao entrar no mundo das crianças, através da literatura, pois a responsabilidade do escritor seria redobrada ao discutir temas impróprios aos seus leitores, disfarçados por elementos mágicos ou maravilhosos”.

\section{3-. Considerações finais}

Para Zilberman (2005, p. 2I), "um escritor é muito popular, quando o mundo que criou escapa a seu controle, como se as personagens vivessem independentemente dele". Lobato pode não ter inventado a técnica de reunir um grupo de figuras com grande presteza para a ação, mas a grande construção lobatiana foi os atributos que ele conferiu a seus personagens: primeiramente, os principais agentes são crianças, ou mimetizam o comportamento delas, sendo que o universo das personagens aproxima-se do mundo do leitor e permite identificação imediata; em segundo lugar, trata-se de um conjunto de seres inteligentes e independentes, dispondo de ampla liberdade para tomar iniciativas, inventar ações originais e resolver problemas, abordam os adultos de igual para igual; por último, as crianças são figuras inseridas na vida brasileira, o que lhes confere autenticidade e nacionalidade, reagem às dificuldades de seu e de nosso tempo, o que mais uma vez facilita a aproximação entre as personagens e o leitor.

Para Ana Maria Machado (2002, p. I26), em razão da riqueza da literatura infantil de Lobato e pelo fato dele ter tido tanto sucesso com as crianças, formando leitores, todos os brasileiros deveriam ter total intimidade com sua obra, seus livros deveriam ser 
leitura obrigatória para todo e qualquer aspirante a professor de que qualquer disciplina.

Para Aguiar (2OOI, p. 2O-2I), Monteiro Lobato foi o primeiro autor da literatura infantil brasileira que deu voz às crianças através das personagens, reproduzindo o universo inquiridor e imaginativo delas, desafiando-as a novas descobertas. Por meio de suas obras, Lobato mostrou que a literatura infantil assegura o status de produção artística quando se vincula ao interesse e à realidade do pequeno leitor. Isso somente ocorre por que o autor compreende que não basta apenas falar sobre a criança a partir da sua posição de adulto que já viveu essa fase da vida. É preciso colocar-se ao lado do leitor, ver o mundo através de seus olhos, levando-o a ampliar esse olhar nas mais variadas direções.

Em razão de tudo que foi dito, podemos dizer que Lobato tem muito a ensinar sobre o gosto do leitor infantil, pois especialmente durante os anos vinte e trinta, houve uma lapidação da sua obra, o que a tornou mais atrativa, fazendo com que ela ultrapassasse os limites cronológicos e viesse a se tornar um clássico lido por muitas gerações. Após a análise das obras que iniciaram e acabaram por definir a estética da literatura infantil lobatiana podemos dizer que ainda há muito a pesquisar, porém algumas considerações podem ser formuladas.

Dessa maneira, Lobato traz um espaço indefinido, um tempo indefinido, a criança como protagonista, o humor, a crítica, a presença do adulto não como autoritarismo, mas como elemento para dar verossimilhança à narrativa, já que crianças não podem viver sozinhas, a formação de palavras, o enxugamento de descrições para um texto de estilo mais direto em que também as protagonistas crianças têm voz e vez, retira a parte cansativa, pedagógica que fazia com que o texto se arrastasse, as personagem passam para uma dimensão mais afetiva, a perfeita harmonia entre fantasia e realidade. Enfim todos esses aspectos e muitos outros que não caberiam neste trabalho, podem ter contribuído para que o autor alcançasse o sucesso que vem tendo durante todos esses anos com o público infantil. 


\section{Referências}

- Aguiar, Vera Teixeira de (Coord.). Era uma vez... na escola: formando educadores para formar leitores. $4^{\text {a }}$. ed. Belo Horizonte: Formato, $200 I$.

- Arroyo, Leonardo. Literatura infantil brasileira. São Paulo: Melhoramentos, I968.

- Cabral, Izaura da Silva. Oleitor em processo de autonomia: contribuições de narrativas clássicas infanto-juvenis. Dissertação de Mestrado apresentada ao PPG-Letras/UNISC, 2007.

- Cavalheiro, Edgar. Monteiro Lobato: vida e obra. $3^{\text {a }}$ ed. São Paulo: Brasiliense, I962.

- Chevalier, Jean; Gheerbrant, Alain. Dicionário de símbolos. i2. ed. Rio de Janeiro: José Olympio, I982.

- Sandroni, Laura. De Lobato a Bojunga. Rio de Janeiro: Agir, I987.

- Lobato, Monteiro. A menina do narizinho arrebitado. Fac-símile da I a . ed. São Paulo: Metal Leve/Forma Composições Gráficas ltda., I982.

- Lobato, Monteiro. A barca de Gleyre. São Paulo: Companhia Editora Nacional, 1944 .

- Lobato, Monteiro. "Narizinho Arrebitado". In: Reinações de Narizinho. São Paulo: Brasiliense, 2005.

- Machado, Ana Maria. Como e por que ler os clássicos universais desde cedo. Rio de Janeiro; Objetiva, 2002.

- Maçolla, Rosangela. As histórias de tradição oral na obra infantil de Lobato: análise folkmidiática em Reinações de Narizinho. Rio de Janeiro: FOLKON, 2003.

- Miguez, Fátima. Nas arte-manhas do imaginário infantil: o lugar da literatura na sala de aula. $4^{\mathrm{a}}$. ed. Rio de Janeiro: Singular, 2009.

- Nunes, Cassiano. Monteiro Lobato vivo. Rio de Janeiro: Mpm, I986.

- Rodrigues, Denise Reis; BORZUK, Cristiane Souza. Monteiro Lobato e o construtivismo Piagetiano: a obra infantil de Monteiro Lobato como suporte na prática pedagógica. XXV Congresso Nacional de Educação - CAJ/ UFG, 2009. Disponível em: www.revistas.jatai.ufg.br/ index.php/acp/article/download/8og/435 Acesso em oI/o8/20II.

- Zilberman, Regina. Como e por que ler a literatura infantil brasileira. Rio de Janeiro: Objetiva, 2005 .

- Zilberman, Regina.. A literatura infantilna escola. São Paulo: Global, 2003. www.lobato.globo.com/biblioteca_Geral.asp Acesso em I5/o7/2OII 